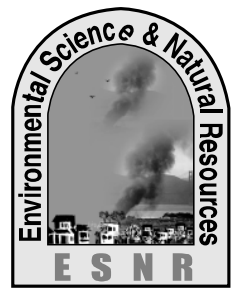

J. Environ. Sci. \& Natural Resources, 7(1): 265-269, 2014

ISSN 1999-7361

\title{
Socio-Economic and Environmental Impacts of Shrimp Culture in Some Selected Areas of Bagerhat District
}

\author{
S. Mitro, R. Khatun and M. A. Baten
}

Department of Environmental Science, Bangladesh Agricultural University, Mymensingh

\begin{abstract}
Socio-economic and environmental impacts analysis of shrimp (Paeneus monodon) farming in the gher area of Bagerhat District is an important aspect where shrimp cultivation increased over the years. An investigation was conducted to evaluate the present socio-economic status as well as to investigate the soil and water quality of the study area. This study has been carried out at ten villages in five Upazilla (Bagerhat Sadar, Rampal, Mangla, Chitalmari and Fakirhat) of Bagerhat District. The socio-economic impact was investigated using questionnaire survey and environmental impact was assessed by analyzing water and soil quality. The soil and water samples were collected during the period of January to March 2013. Maximum people of this study area were involved in shrimp culture because soil is not suitable for agricultural crops due to high salinity percentage. Annual family income of maximum number (45\%) of farmers was greater than 200000 taka per year from shrimp culture. All the soil $\mathrm{p}^{\mathrm{H}}$ value was neutral to slightly alkaline. Shrimp culture has no noticeable impact on soil quality. On the other hand, shrimp culture has some negative impacts on water quality such as, the range of $\mathrm{K}$ and $\mathrm{Na}$ in water has been increased and the range of $\mathrm{Ca}$ has been decreased than normal range. However, it is very minor compared to annual income from this culture. Therefore, the people of this region may involve more in shrimp culture.
\end{abstract}

Key words: Shrimp culture, socio-economic impacts, environmental impacts.

\section{Introduction}

Bangladesh provides her people with various occupations, not only in cities, but also in her rural society. However, changes in occupation have been discerned with the touch of modern science and technology and thus new occupations have emerged. Of all the occupations, shrimp cultivation meanwhile gets popularity in the southwest region specially Bagerhat of Bangladesh. Economic gain is the ambitious key behind the shrimp cultivation that is exerting an impact on rural socio-economic life-style. Cultivation of shrimp in a controlled and enclosed water body is described as shrimp culture or in general 'the cultivation of shrimp'. Bangladesh is considered one of the most suitable countries in the world because of its favorable resources and agroclimatic conditions. The southwestern region of Bangladesh is known as the main zone of shrimp cultivation and about $75 \%$ of country's shrimp production is obtained from this region (Huq et al., 2004). Shrimp cultivation in the coastal areas of Bangladesh particularly in the greater Khulna Division has been practiced for the centuries (Rahman et al., 2006)

Shrimp farming and related activities contribute significantly to the national economy of Bangladesh (BER, 2010). The main areas of contribution are export earning and employment generation for on and off farm activities (Ahmed, 2001; Siddique, 2009). Fisheries sector contributes $4.57 \%$ to the Gross Domestic Product (GDP) and shrimp alone contributes about $0.07 \%$ of total export earnings
(BER, 2010). Shrimp is the third largest foreign exchange earning commodity, after garment and jute, contributing $9 \%$ to national export earnings.

However, people of the study area also thought that water becomes more turbid, odorous and less tasty for shrimp cultivation. High levels of turbidity over long periods can greatly diminish the health and productivity of the pond water ecosystem in the coastal area (Elmanama, 2006). In this area, crop cannot grow properly due to high saline condition. The situation becomes more alarming when its effects have changed the overall ecosystem of the coastal areas and destroyed the agriculture, vegetation, livestock and poultry.

There have been several studies on the relationship between shrimp culture and the environment, which recognize that shrimp culture has direct environmental impacts. However, the significance of environmental and social impacts of shrimp culture is poorly understood in Bangladesh. Considering the above views, the study was carried out to investigate the socio-economic impact of shrimp culture and to assess the impact of shrimp culture on soil and water environment.

\section{Materials and Methods}

\section{Selection of the study area}

The study was carried out at Fakirhat, Chitalmari, Bagerhat Sadar, Rampal, and Mangla upazilla of Bagerhat district from January to March 2013. The study was conducted in 10 selected villages of these 
five Upazillas under Bagerhat district. The villages are selected on the basis of certain sets of criteria such as: these areas are very promising for freshwater prawn; the areas having extensive shrimp culture; shrimp farming has been going on for at least ten years in the areas; shrimp is the main crop and major share of income of the farmers of these area; commercial prawn farming is usually done in these areas.

\section{Data collection and analysis}

The socio-economic impact analysis was based on field survey where primary data were collected from individual farmers through direct interview. One hundred respondents were interviewed for this purpose. Farmers were selected through simple random sampling method. Age, gender, education, major profession, annual income, land holding, and credit source were considered as independent variable and the dependent variable was the level of knowledge on shrimp farming and environmental issues of the farmers.

To investigate the impact of shrimp culture on soil and water environment, soil and water samples were collected from each Upazilla and brought to the laboratory for physical and chemical analysis. Each soil sample was kept separately on a brown paper and mixed thoroughly. About $1 \mathrm{~kg}$ of soil was collected from each place to give a representative sample. Samples were placed in sealed polythene bags that were labeled to avoid any damage. The level contained the name of the places, date of collection and code number of soil sample. For assessment of water quality, 10 water samples were collected from five Upazilla and were stored in plastic bottle.
Soil texture i.e. \% sand, silt and clay determinations were carried out by hydrometer method as outlined by Bouyoucos (1927). Organic matter (OM) was done by wet oxidation method. The percent organic carbon of the collected soil samples were determined by wet oxidation method developed by Walkley and Black (1996). Total nitrogen in the soil was determined by micro Kjeldahl method. For both soil and water sample: $\mathrm{pH}$ was determined by glass electrode $\mathrm{pH}$ meter; electrical conductivity (EC) was measured electrometrically; phosphorous (P) was determined calorimetrically by Olsen's method; exchangeable potassium (K) was determined by Ammonium acetate extraction method; sodium $(\mathrm{Na})$ was determined by flame emission spectrophotometer; calcium (Ca) was determined by titration method using $\mathrm{Na}_{2}$ EDTA and sulphur (S) was determined by turbidimetric method with the help of a spectrophotometer.

\section{Results and Discussion Socio-economic Impact}

The distribution of the respondents according to various age groups is an important aspect because experienced farmers are more suitable for shrimp culture. In this study, old aged farmers i.e., experienced farmers were maximum and their percentage was 39. Among the respondents, 29\% were up to primary, $24 \%$ up to SSC and $7 \%$ had higher degree. Maximum farmers were under medium family size category (5-6 members).

In the study, it is observed that maximum farmers had medium homestead land area (20-40 decimal). On the other hand, maximum farmers had low own gher area ( $<100$ decimal). Most of the farmers (84\%) were landless in case of cultivated land (Table 1).

Table 1 Farm size of the study area

\begin{tabular}{|c|c|c|c|c|}
\hline Farm size & Types & Percent & Mean & SD \\
\hline \multirow[t]{4}{*}{ Homestead area } & Landless (0) & 5.0 & \multirow{4}{*}{28.13} & \multirow{4}{*}{10.89} \\
\hline & Low $(<20$ decimal $)$ & 26.0 & & \\
\hline & Medium (20-40 decimal) & 58.0 & & \\
\hline & High (>40 decimal) & 11.0 & & \\
\hline \multirow[t]{4}{*}{ Gher area own } & Landless (0) & 35.0 & \multirow{4}{*}{66.88} & \multirow{4}{*}{61.16} \\
\hline & Low $(<100$ decimal $)$ & 37.0 & & \\
\hline & Medium (100-150 decimal) & 20.0 & & \\
\hline & High (>150 decimal) & 8.0 & & \\
\hline \multirow[t]{4}{*}{ Cultivated land } & Landless (0) & 84.0 & \multirow{4}{*}{2.97} & \multirow{4}{*}{8.59} \\
\hline & Low $(<10$ decimal $)$ & 2.0 & & \\
\hline & Medium (10-20 decimal) & 7.0 & & \\
\hline & High $(>20$ decimal $)$ & 7.0 & & \\
\hline
\end{tabular}


In this study, annual family income was calculated from shrimps, agriculture (crops, fruits, trees, and livestock's) and others (services, day labors, business, fishes except shrimp etc.). Majority of the farmers (94\%) were involved with shrimp culture and annual family income of maximum number $(45 \%)$ of farmers from shrimp culture was greater (>200000 tk/year) compared to other services (Table 2). Annual income from agriculture is not so high because, the soil is not suitable for agricultural crops due to high salinity percentage. A few numbers of people (16\%) were involved in other income generating activities.

Table 2 Annual family incomes

\begin{tabular}{|c|c|c|c|c|}
\hline $\begin{array}{c}\text { Source of } \\
\text { income }\end{array}$ & Amount & Percent & Mean & SD \\
\hline \multirow[t]{3}{*}{ Shrimp } & $\begin{array}{c}\text { Low } \\
(50000-150000 \mathrm{tk})\end{array}$ & 29.8 & \multirow{3}{*}{439042.5} & \multirow{3}{*}{732020.06} \\
\hline & $\begin{array}{c}\text { Medium } \\
(150000-200000 \mathrm{tk})\end{array}$ & 22.3 & & \\
\hline & High $(>200000$ tk) & 47.9 & & \\
\hline \multirow[t]{3}{*}{ Agriculture } & Low $(50000-150000 \mathrm{tk})$ & 28.26 & \multirow{3}{*}{201612.90} & \multirow{3}{*}{243048.89} \\
\hline & $\begin{array}{c}\text { Medium (150000-200000 } \\
\text { tk) }\end{array}$ & 41.30 & & \\
\hline & High (>200000 tk) & 30.43 & & \\
\hline \multirow[t]{3}{*}{ Other sources } & Low (50000-150000 tk) & 12.5 & \multirow{3}{*}{236250.00} & \multirow{3}{*}{214751.79} \\
\hline & $\begin{array}{c}\text { Medium (150000-200000 } \\
\text { tk) }\end{array}$ & 43.8 & & \\
\hline & High (>200000tk) & 43.8 & & \\
\hline
\end{tabular}

In view point of environmental awareness, maximum farmers $(60 \%)$ opined that shrimp culture had negative impact

on soil and water environment. In addition, $64 \%$ said about biodiversity decreases; $35 \%$ said about health hazard mainly skin problems due to shrimp culture.

\section{Environmental Impact}

In field survey, majority of the respondent said that, due to shrimp culture, soil and water quality of the gher area were decreased. Therefore, to find out the impact of shrimp culture on soil and water environment, soil and water quality were also assessed in this study.

\section{Impact on soil environment}

The soil texture of the study area was mainly silt loam, silty clay and clay loam. The chemical properties of soil were presented in Table 3 . According to Table 3 , the $\mathrm{p}^{\mathrm{H}}$ values ranged from 7.34 to 7.76 with the mean value 7.34 and standard deviation 0.16 . All the soil $\mathrm{p}^{\mathrm{H}}$ value was neutral to slightly alkaline and it can be said that shrimp culture had no effect on soil $\mathrm{p}^{\mathrm{H}}$. The soil EC values ranged from 729 to $1084 \mu \mathrm{s} / \mathrm{cm}$ with the mean value 729 and standard deviation 131.28. The soil EC was permissible in the study area. The organic matter content ranged from $1.37 \%$ to $3.47 \%$ with the mean value 1.98 and standard deviation 0.77 . Total organic matter in this area was low to high. The low level of organic matter in some areas might be due to higher oxidation rate of plant and animal residues by relatively high temperature. The organic carbon ranged from $0.79 \%$ to $2.0 \%$ with the mean value 1.14 and standard deviation 0.44 . Total nitrogen content ranged from 0.07 to $0.17 \%$ with their mean value 0.09 and SD 0.04. Very minor differences were found among the areas and it was in suitable range as recommended rate is $<1 \%$. The amount of available phosphorous ranged from 28.04 to $41.36 \mathrm{ppm}$ with their mean value 33.14 and standard deviation 4.62. The available Na ranged from 560.75 to $676.72 \mathrm{ppm}$. Their mean value was 628.88 and standard deviation was 57.32. The available $\mathrm{Ca}$ ranged from 646.68 to $1541.62 \mathrm{ppm}$ with mean value 944.85 and standard deviation 355.19. The available $\mathrm{S}$ content ranged from 64.25 to $246.32 \mathrm{ppm}$. The available $\mathrm{S}$ contents of soils showed wide variation among the study sites. 
Table 3 Soil chemical properties

\begin{tabular}{|c|c|c|c|c|c|c|c|c|}
\hline Location & $\begin{array}{l}\text { OM } \\
\%\end{array}$ & $\begin{array}{l}\text { Org C } \\
\% \\
\end{array}$ & $\begin{array}{l}\text { Total N } \\
(\%)\end{array}$ & $\begin{array}{l}\mathrm{P} \\
(\mathrm{ppm}) \\
\end{array}$ & $\begin{array}{l}\mathrm{K} \\
(\mathrm{ppm})\end{array}$ & $\begin{array}{l}\mathrm{Na} \\
(\mathrm{ppm})\end{array}$ & $\begin{array}{l}\mathrm{Ca} \\
(\mathrm{ppm})\end{array}$ & $\begin{array}{l}\text { S } \\
(\mathrm{ppm})\end{array}$ \\
\hline \multirow[t]{2}{*}{ Bagerhat sadar } & 1.68 & 0.97 & 0.08 & 32.55 & 225.0 & 676.74 & 811.92 & 151.71 \\
\hline & 1.71 & 0.99 & 0.08 & 32.52 & 225.0 & 676.70 & 811.90 & 151.68 \\
\hline \multirow[t]{2}{*}{ Fakirhat } & 1.81 & 1.04 & 0.09 & 31.75 & 251.3 & 672.72 & 1079.13 & 88.20 \\
\hline & 1.75 & 1.01 & 0.08 & 31.72 & 251.3 & 672.70 & 1074.10 & 88.32 \\
\hline \multirow[t]{2}{*}{ Chitlmari } & 3.40 & 1.96 & 0.17 & 28.04 & 227.0 & 670.36 & 1541.62 & 64.28 \\
\hline & 3.47 & 2.00 & 0.17 & 28.08 & 227.0 & 670.30 & 1540.72 & 64.25 \\
\hline \multirow[t]{2}{*}{ Rampal } & 1.43 & 0.83 & 0.07 & 32.05 & 233.1 & 563.95 & 647.48 & 195.14 \\
\hline & 1.37 & 0.79 & 0.07 & 32.08 & 233.2 & 563.90 & 646.68 & 194.72 \\
\hline \multirow[t]{2}{*}{ Mangla } & 1.59 & 0.92 & 0.08 & 41.36 & 237.1 & 560.76 & 647.48 & 246.28 \\
\hline & 1.68 & 0.97 & 0.08 & 41.30 & 237.2 & 560.74 & 647.50 & 246.32 \\
\hline Mean & 1.98 & 1.14 & 0.09 & 33.14 & 334.72 & 628.88 & 944.85 & 149.09 \\
\hline SD & 0.77 & 0.44 & 0.04 & 4.62 & 9.86 & 57.32 & 355.19 & 70.63 \\
\hline
\end{tabular}

\section{Impact on water environment}

The chemical properties of water of the study area were presented in Table 4. The $\mathrm{p}^{\mathrm{H}}$ value ranged from 6.67 to 7.26 with mean value 7.08 and standard deviation 0.24 . The results indicated that all the samples of the study area were neutral to slightly acidic. The water $\mathrm{p}^{\mathrm{H}}$ was in the suitable ranges as drinking water $\mathrm{p}^{\mathrm{H}}$ ranges from 6.5-8.5. Therefore, it can be said that, shrimp culture has no negative impact upon water $\mathrm{p}^{\mathrm{H}}$. The $\mathrm{EC}$ value ranged from 2880 to $4080 \mu \mathrm{s} / \mathrm{cm}$ (Table 4) with mean value 3499.60 and standard deviation 810.90. Average salinity in these areas was medium to high and water was doubtful to good condition. In Mongla Upazilla, salinity percent is higher due to intrusion of water from Bay of Bengal. From the Table 4, it is found that the available $\mathrm{P}$ in the study area ranged from 0.50 to1.06 ppm. The $\mathrm{P}$ content in the study area was within the range of standard value (0.003-4.4 ppm). The available K ranged from 3.447 to 42.78 ppm with mean value was 26.68 and standard deviation was 16.46. The normal range of $\mathrm{K}$ is 0.01 to 26.0. The results indicate that $\mathrm{K}$ is higher in some study areas. The available $\mathrm{Na}$ of study area ranged from 39.38 to $234.6 \mathrm{ppm}$ (Table 4) whereas the normal range is $0.26-30$. The Na range is higher than normal range. So, it might have negative impact on water quality. The available $\mathrm{Ca}$ ranged from 41.10 to $61.78 \mathrm{ppm}$ (Table 4) which was under the normal range. The available $\mathrm{S}$ ranged from 46.26 to $53.83 \mathrm{ppm}$ with mean value 48.23 and standard deviation 4.61 . The available $S$ contents of water showed minor variation among different locations.

Table 4 Chemical properties of water

\begin{tabular}{|l|c|c|c|c|c|c|c|}
\hline $\begin{array}{l}\text { Sampling } \\
\text { Location }\end{array}$ & $\mathrm{p}^{\mathrm{H}}$ & EC ms/cm & $\begin{array}{c}\text { Available P } \\
(\mathrm{ppm})\end{array}$ & $\begin{array}{c}\text { Available K } \\
(\mathrm{ppm})\end{array}$ & $\begin{array}{c}\text { Available } \\
\text { Na (ppm) }\end{array}$ & $\begin{array}{c}\text { Available Ca } \\
(\mathrm{ppm})\end{array}$ & $\begin{array}{c}\text { Available S } \\
(\mathrm{ppm})\end{array}$ \\
\hline Bagerhat Sadar & 7.26 & 3610 & 1.062 & 3.447 & 234.6 & 41.107 & 52.68 \\
\hline Fakirhat & 6.67 & 2088 & 0.54 & 15.83 & 39.38 & 61.78 & 44.39 \\
\hline Chitalmari & 7.16 & 3740 & 0.51 & 34.55 & 76.69 & 51.57 & 46.33 \\
\hline Rampal & 7.24 & 3980 & 0.5 & 42.78 & 169.18 & 61.38 & 44.26 \\
\hline Mangla & 7.10 & 4080 & 0.63 & 36.85 & 191.74 & 41.10 & 53.83 \\
\hline Mean & 7.08 & 3499.60 & 0.64 & 26.68 & 142.32 & 51.38 & 48.23 \\
\hline SD & 0.24 & 810.90 & 0.23 & 16.46 & 81.52 & 10.24 & 4.61 \\
\hline
\end{tabular}

The results revealed that, all the soil and water quality parameters in the study area were within standard range or near to standard value. Therefore, it can be said that shrimp cultivation is not harmful for soil and water quality in the study area.

\section{Conclusion}

Shrimp is a cash crop which creates employment opportunities and improves the livelihood of shrimp farmers as well as related intermediaries. Therefore, shrimp industry is an important and potential sector for economic development in Bangladesh. In this study, all respondents reported that although they are 
facing some problems in shrimp farming and marketing activities, their livelihood is gradually improving. Shrimp cultivation has ecological impact in terms of salinity increase and loss of biodiversity. In spite of some negative impacts on ecology, the economic importance of shrimp cannot be overlooked for a developing country like Bangladesh. Proper management and planning may give a sustainable growth and benefit of shrimp cultivation.

\section{References}

Ahmed, N. 2001. Socio-economic aspects of freshwater prawn culture development in Bangladesh. $\mathrm{PhD}$ thesis, Institute of Aquaculture, University of Stirling, UK, pp. 3-20.

BER (Bangladesh Economic Review). 2010. Economic Adviser's Wing. Finance Division, Ministry of Finance. Government of the People's Republic of Bangladesh.

Bouyoucos, G.J. 1962. Hydrometer method improved for the mechanical analyses of soil.

Agronomy J.,54:464.
Elmanama, A. A.; Afifi, S. and Bahr, S. 2006. Seasonal and Spatial Variation in the Monitoring Parameters of Gaza Beach during 2002-2003, Environmental Research, 101: $25-33$.

Huq, K. A.; Monir, S.M.I.; Rahmn, M. M. and Ferdous, K. S. 2004. Production performance of Macrobrachium rosenbergii(de Man) in monoculture versus polyculture system. Journal of Bangladesh Agricultural University. 2(1): 141-149.

Siddique, M. H. 2009. A case study on Shrimp Culture Activities and its Socio-Economic and Environmental Impacts in the Southern Coastal Region of Bangladesh. Norwegian College of Fishery Science, University of Tromso, Norway.

Walkley, A. and Black, I. A. 1934. An examination of the Degtjareff method for determining organic carbon in soils: Effect of variations in digestion conditions and of inorganic soil constituents. Soil Sci., 63:251-263. 